\title{
Supporting Students' Literacy in Writing Popular Articles Using a Social Media Application
}

\author{
Nurul L. Rochmah ${ }^{1, *}$ \\ ${ }^{1}$ Kementerian Agama Kabupaten Banyuwangi MAN 1 Banyuwangi, Banyuwangi, Indonesia \\ *Corresponding author. Email: upikdfibanyuwangi@gmail.com
}

\begin{abstract}
This study aims to describe the process and results of using the WhatsApp application as a medium for assisting in writing popular articles for students at the beginning of the COVID-19 pandemic to support their literacy development. The subjects of this study were 180 twelfth grade students of MAN 1 Banyuwangi (Islamic State Senior High School). The focus of this research was the process of writing mentoring and the results obtained after the mentoring had been completed. Methods of collecting data were interviews, discussions, and questions and answers. The data were analyzed by using qualitative descriptive techniques. This research shows that at the beginning of the Covid-19 pandemic, WhatsApp was the most suitable to be used as a medium to assist students in writing popular articles. The stages of mentoring carried out included themes, drafting designs, finding materials, developing designs into complete writing, and editing. The results obtained by students after the mentoring process using the WhatsApp application were that students could write popular articles with good categories for the suitability of themes and content, sentence composition and diction selection, paragraph cohesion and coherence, and use of written language. As many as 30 of the 180 popular articles written by students as a result of this mentoring were successfully published in the mass media. Based on the results of this study, it is recommended that teachers use digital applications to facilitate the process of personal and intensive mentoring in writing popular articles to get better results.
\end{abstract}

Keywords: Writing popular articles, WhatsApp, Mentoring, Covid-19 Pandemi, Literacy.

\section{INTRODUCTION}

Pandemic period has changed the learning system that we have been doing for years. Classroom learning is being replaced by online learning [1]. Learning methods and media have also changed [2] Assistance in learning to write before the pandemic is always done directly in the classroom classically or individually. Face-to-face learning will make it easier for teachers to give instructions to improve writing on the spot. The teacher can also guide students to find correct sentences. Oral discussion accelerates students' understanding of the material that must be improved. All those things are difficult to implement at the beginning of the pandemic.

At the beginning of the pandemic, teachers and students were both confused about starting distance learning. Teachers have difficulty in finding the right media for learning to write popular articles. Not all students have supported devices. Network, signal, and quota constraints are often a problem. Teachers and students are also not proficient in using various online learning media. One of the digital media that can be reached by all circles at that time was WhatsApp. Through the WhatsApp application, we can send document files, photo files, voice messengers, video calls, GPS locations, emoticons, broadcasts, and others [2]. These features of WhatsApp can be used to assist in writing popular articles in small groups and individuals.

Writing skill is still considered a difficult learning material among high school students, including writing a popular article. This learning material is considered difficult to acquire since it is a part of complex language skills [8]. Writing involves other language skills, such as listening, speaking, and reading. Lack of reading interest makes it even more difficult for students to write. Teachers also play a significant role regarding the problem mentioned. They do not give specific time to coach the students during the process of writing a popular article. 
Writing popular articles is relatively easier than writing scholarly articles. Kuntarto [10] stated that popular articles are less strict in terms of conventions and linguistic rules compared to scholarly articles. Popular articles are published on mass media, and it has its own characteristics. Those characteristics are; shorter than scholarly articles, talking about the actual theme, using interesting and communicative word-choice. They also tend to show personal opinions, although they also use experts' opinions, theories, or research findings to strengthen the author's arguments. Those characteristics and less strict rules make it possible for students to master this learning material.

Some activities about assisting students to write popular articles have been conducted. Sudarmini [17] conducted a coaching clinic on the use of how to write popular articles for the teachers of junior secondary school SMP Unggulan Aisyiyah Bantul, Jogjakarta. The study showed that the mentoring and assistance activities were conducted using the article usage method. Writing assistance using WhatsApp media had also been done. Pahriah [13] assisted in writing textbooks for novice lecturers. The data and the mentoring process were well explained and applied to the mentoring process for high school students. Based on the results of the previous study, the type of assistance in writing popular articles for high school students has not been found using WhatsApp media. Therefore, it is very important to carry out assistance in writing popular articles for high school students.

The purpose of this assistance is to make each student get assistance in writing popular articles effectively through WhatsApp and to make students able to write articles according to the criteria for good popular article writing.

\section{METHODS}

The research was conducted on 180 twelfth grade students of MAN 1 Banyuwangi (Islamic Public Senior High School), majoring Science Program (IPA). The subject of this study was chosen because the author is a teacher of Indonesian language and literature in these classes. The material for writing opinions and articles was in the odd semester. Before the pandemic, popular article writing materials were taught, completed, and compiled in the form of anthology books. During the pandemic, this material was taught and completed with a target that is worthy of being sent to the mass media.

This study used qualitative research methods [6] [17]. Data collection was interactive with data analysis.
Data collection was carried out simultaneously with data analysis activities. The data were reduced by summarizing and sorting according to the category or concept. In this study, data were obtained by observing and accompanying the process of writing these popular articles. This intensive mentoring process was recorded and described in a detailed description. The results obtained in this assistance were presented in tabular form. Further meaning based on the results of this mentoring process was also given in the discussion section.

In the mentoring process for writing this popular article, teachers and students conducted discussions, question and answer, practice, and consultation. Students were given the material on the concept of writing popular articles, how to make writing designs, how to make interesting paragraph beginnings, how to develop paragraphs, titles, and the basics of writing. The teacher briefing was held in an online meeting using the WhatsApp group [5]. Practice and consultation until writing an article were also completed using WhatsApp media.

Mentoring was more individualized using chat and voice messenger facilities on WhatsApp. The choice of this method was because each student's ability to write is different and requires different directions. In addition, mentoring through WhatsApp was easier, able to be done anywhere, and able to be adjusted to the time of mentoring. The role of the teacher in this mentoring was very important. Teachers had to do several things quickly, including responding to WhatsApp quickly, initiating intensive communication, providing clear and directed input, and giving appreciation for students' writing progress. The effectiveness of WhatsApp as an online learning medium for assistance in writing popular articles was measured based on the intensity of interaction in the chat room and the time of completion of writing articles according to the schedule [22].

The procedure for mentoring popular article writing for students was carried out in several stages, including planning, implementation, correction, improvement, editing, and completion [9]. Briefly, each of these stages is explained as follows.

\subsection{Planning Phase}

Students get an explanation on how to write popular articles including actual themes, making designs or outlines of the contents of the writing, searching for writing materials, developing drafts of writing, using popular and communicative language, and 600-700 
words for the length of the writing. This explanation was given classically by the teacher. This planning stage was carried out in the first month.

\subsection{Implementation Phase}

After the draft was completed and approved, each student began to develop the written design into a complete article. At this stage, the teacher accompanied each process of student work, paid attention to the contents of the writing in detail, provided input on which parts need to be improved, and gave appreciation for the parts of writing that are already good. This phase was carried out in the second month.

\subsection{Proofreading Phase}

If the writing of this article had been completed, the teacher should correct the article as a whole including the possibility of plagiarism and how to overcome them. This stage was carried out in the third month.

\subsection{Correction Phase}

Students' writings that required correction of the contents were returned and students were asked to make corrections, including some parts of writing that are classified as plagiarism. The teacher gave directions, for example, summarizing the opinions of other authors used in writing and mentioning the source of the text. This stage was carried out in the fourth month.

\subsection{Editing Phase}

Students who had completed the writing without major correction accompanied the teacher to correct their friend's work. Teachers can take advantage of some children who are deemed capable of doing peer-editing activities. In the end, the teacher had to do the final editing of the student's writing. This stage was performed in the fifth month.

\subsection{Finalizing Phase}

At this stage, the students' writing was considered complete and categorized as good. The results of the students' writing were equipped with self-identity and photographs to be sent to the media as a form of trial eligibility. This process matters to increase the confidence of the students in writing popular articles of opinion.

\section{RESULTS AND DISCUSSIONS}

Assistance in writing popular articles was carried out to 180 twelfth grade students of MAN 1 Banyuwangi. They were grouped into five WhatsApp groups. Assistance was provided within six months [18]. It was from July 2020 until December 2020.

\subsection{Planning Stage}

At this stage, the teacher gave the freedom to write the theme and design interest. The theme was freely chosen by the students in order to make them easy for writing as it related to their enthusiasm for finding material. Although they were given the freedom to choose a theme, it had to be consulted first. The goal was that teachers could give consideration, guidance, and feedback. Consideration is including giving input about the actuality of the theme, how interesting the theme is, how important the theme is read by readers, and the benefit of the theme when it was written. Based on the following data, several themes were chosen by students [12]

Table 1. Article Theme

\begin{tabular}{|c|c|c|}
\hline NO & Theme & Number of students \\
\hline \hline 1 & Learning problems during the pandemic & 28 \\
\hline 2 & Taking advantage of free time during distance learning & 25 \\
\hline 3 & Maintaining the health of future pandemic & 7 \\
\hline 4 & Pandemic and economic & 32 \\
\hline 5 & Corona and its implications & 15 \\
\hline 6 & Social media and millennials & 16 \\
\hline 7 & Job opportunities & 27 \\
\hline 8 & At the stage of choosing the theme, each & \begin{tabular}{c} 
limited so students could ask as often as possible \\
through the chat room. The theme was approved by the \\
\hline
\end{tabular} \\
student had used it more than three times to get approval \\
for the theme to be used. Consultation time was not
\end{tabular}


$68 \%$ of students chose the theme around pandemics and bold learning and $32 \%$ of students chose the social media theme for millennials.

After the theme was approved, students were asked to outline the writing. This outline was used by the teacher to measure students' consistency in expressing ideas. An outline could be in the form of important points of writing an article plan. If students had difficulty in making an outline, the teacher could direct it in the form of prompting questions. The examples of such questions were: Can this concept be elaborated? Is there a relationship between statements A and $\mathrm{B}$ ? Has the concept been given an example? What keywords can be used for this statement? In addition, conversations via voice notes could also be used to check students' ability to outline writing plans.

To indicate the students' understanding of what they would write, they should be able to explain orally the outline they made. Based on the findings in the field, students could explain what would be written but not yet coherent. The teacher's job was to help sort it out. Some could convey an outline but needed to develop a discussion of the problem or theme to be written. The teacher had to be able to assist students in finding other things that could be related and compared to the theme that would be written.

\subsection{Implementation Stage, Proofreading, and Editing}

After the preparation of the outline writing had been completed, students were asked to continue the step of looking for written material by reading various articles, journals, papers, or books related to the theme. While searching for materials, students were not allowed to copy and paste the materials arbitrarily. All students had to use the correct citation process. They were encouraged to carry out the process of summarizing the reading if they wanted to quote other people's opinions and include them in the source.

When the material was considered sufficient, students were accompanied for the writing process. WhatsApp application was used as a bridge of communication with students for the repairing process of writing articles. This mentoring method was chosen because the improvement of writing results was individual. Each student could write different articles. Some were quick to respond to the input given and some still needed several explanations.

Communication via WhatsApp was also documented in the form of a google form that was stored in the drive and shared with students as a whole. In the form, there was a file written for each student's article as well as corrections and suggestions for improvement. The goal is to speed up the process of improving the work of writing articles for each student. They could see the work of a friend who already corrected and could compare it with his work.

The next step in the process of this assistance was to edit the writing language conducted by the teacher. Teachers could also carry out activities to create peer tutors. In one class, 2-4 people were selected who are considered to have better writing skills than the others. They were given a special course that covers basic editing typo, spelling, and punctuation. Their peer tutors assisted teachers in editing writing assignments student articles.

Table 2. Writing Assistance Process

\begin{tabular}{|c|c|c|c|c||}
\hline \multirow{2}{*}{ No } & Phases Of Assistance Through Whatsapp & \multicolumn{2}{|c|}{ Student Responses To The Assistance Process } \\
\cline { 3 - 5 } & & Great & Sufficient & Deficient \\
\hline 1 & Deciding on a theme & 130 & 30 & 20 \\
\hline 2 & Drafting or writing outline & 130 & 35 & 25 \\
\hline 3 & Looking for writing materials or sources & 138 & 37 & 5 \\
\hline 4 & Elaborating a draft to be full article & 140 & 38 & 4 \\
\hline 5 & Conducting edit the contents article & 150 & 28 & 3 \\
\hline 6 & Carrying out editing activities in written & 160 & & - \\
\hline
\end{tabular}


Table 3. Proofreading and Editing Writing

\begin{tabular}{|c|c|c|c|c|}
\hline \multirow{2}{*}{ NO } & Article Content And Language Analysis & \multicolumn{2}{|c|}{ Results Obtained by Students } \\
\cline { 3 - 5 } & & Great & Sufficient & Deficient \\
\hline 1 & Conformity of content and theme & 100 & 50 & 30 \\
\hline 2 & Preparation of sentence & 120 & 33 & 27 \\
\hline 3 & Choice of word/diction & 123 & 30 & 27 \\
\hline 4 & Paragraph cohesion and coherence & 125 & 30 & 25 \\
\hline 5 & Writing language & 135 & 30 & 15 \\
\hline
\end{tabular}

\subsection{Completion Stage}

Articles that had gone through the process of correction, editing, and had been declared complete, needed to have the opportunity to be published [7]. The way to do this was to send the article to the mass media. Selection in the hands of the editor was certainly not easy. However, the success of being published and read by the wider community became a motivation to submit articles to the media. The publication of the articles written by the class XII IPA (natural science) students was a good achievement considering that this had never happened before. These results increased students' confidence that they could write articles well.

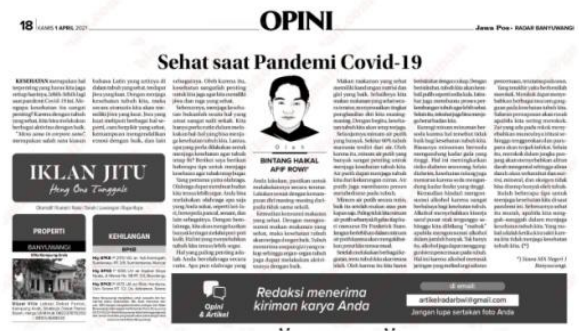

Figure 1. One of the results of mentoring popular article writing using the WhatsApp application that was successfully published in newspapers.

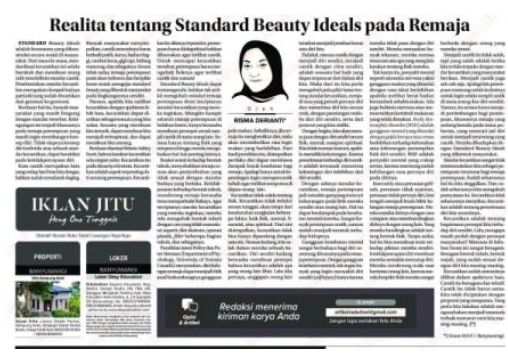

Figure 2. One of the results of mentoring popular article writing using the WhatsApp application that was successfully published in newspapers;

The mentoring process was personal and the time used for mentoring was also flexible. The teacher had the opportunity to provide intensive guidance with each student in the WhatsApp chat room. Teachers could provide responses and revisions of writing quickly so that students could immediately correct it. Teachers also had the opportunity to give appreciation to the work of students who were progressing. This appreciation played an important role in boosting students' enthusiasm for writing [18]. The drawback was that if the teacher did not have enough time, the assistance could be neglected. The advantage was that if the teacher was really serious and painstaking in handling this mentoring process, the results obtained were also maximum.

WhatsApp learning media also had limitations. Among them, the data was not well documented and manual. A lot of chats made the cellphone memory full so the internet connection was slow and quite tiring because users had to go back and forth to see the chat from the beginning of learning [11]. However, at the beginning of the pandemic, online learning models and media were still limited and had not been mastered by teachers or students. At that time WhatsApp became the most familiar and easiest means of distance learning or online learning. WhatsApp media was also the most accessible and inexpensive compared to other elearning-based learning media such as zoom meetings, google meet, which require or absorb more quota. WhatsApp was most widely used by students, especially those who live in villages or remote places. The use of WhatsApp for learning was also happening elsewhere. [1] [4]

Compared to the research conducted by Sudarmini [17] and Pahriah [13], this study has a higher level of difficulty because it is the students who are faced with it. The benefit of this research is that the teacher can know every learning process carried out by each student in the activity of writing popular articles and can provide an assessment according to the ability of the students.

\section{CONCLUSION}

The mentoring process for writing popular articles in order to support students' literacy development using WhatsApp media makes every student feel that they are continuously monitored and appreciated every step of 
the way they write. WhatsApp media makes communication and mentoring more intensive, flexible, and focused. The attention, patience, quick response, and appreciation of the teacher in assisting play an important role in the success of the mentoring process in writing this popular article. The encouraging thing in this assistance is the success of high school students in writing popular articles and being published in the mass media (newspapers). This feat was unprecedented. The writing of papers on the process of mentoring popular article writing for students has not been done by many people so that further researchers can still explore this topic. Recommendations that can be given to researchers who are interested in conducting similar research are the opportunity to compare WhatsApp media with other online learning media or try other digital media to take an inventory of students' popular article writing work and provide assistance more effectively. Future researchers can also research to find more effective article writing mentoring techniques for students at lower levels such as in SMP/MTs (junior high school).

\section{AUTHORS' CONTRIBUTIONS}

All authors conceived and designed this study. All authors contributed to the process of revising the manuscript, and in the end, all authors have approved the final version of this manuscript.

\section{REFERENCES}

[1] A. Oriji, F. P. Anikpo, Social media in teachinglearning process: Investigation of the use of Whatsapp in teaching and learning in University of Port Harcourt, European Scientific Journal 15(4), 2019, pp. 15-39.

[2] B. A. Hughes, J. Stallard, C. C. West, The use of Whatsapp $\mathbb{R}$ as a way to deliver plastic surgery teaching during the COVID-19 pandemic, Journal of Plastic, Reconstructive \& Aesthetic Surgery 73(7), 2020, pp. e1-e2.

[3] N. D. Indrilla, S. Ciptaningrum, An approach in teaching writing skills: does it offer a new insight in enhancing students' writing ability, LLT Journal: A Journal on Language and Language Teaching 21(2), 2018, pp. 124-133.

[4] C. Madge, et al., WhatsApp use among African international distance education (IDE) students: transferring, translating and transforming educational experiences, Learning, Media and Technology 44(3), 2019, pp. 267-282.
[5] E. Indaryani, D. Suliworo, Dampak pemanfaatan WhatsApp dalam meningkatkan motivasi belajar siswa pada pelajaran fisika, Quantum: Seminar Nasional Fisika, dan Pendidikan Fisika, 2018, pp 25-31.

[6] H. Basri, Using qualitative research in accounting and management studies: not a new agenda, Journal of US-China Public Administration 11(10), 2014, pp. 831-838.

[7] H. Ibda, Peningkatan Kompetensi Profesional Guru Sd/Mi Melalui Menulis Di Media, Tarbawi: Jurnal Pendidikan Islam 14(1), 2017.

[8] H. Ibda, Bahasa Indonesia tingkat lanjut untuk mahasiswa: Dilengkapi caturtunggal keterampilan berbahasa, CV. Pilar Nusantara, 2019.

[9] M. N. Sulton S. Idris, Y. Mulyati, Strategi 3-M (Mengumpulkan Bahan, Menulis, Menyunting) Dalam Pembelajaran Menulis Di Sma, Seminar Internasional Riksa Bahasa. 2020.

[10] N. M. Kuntarto, Mencitarasakan Kalimat Dalam Menulis Artikel Populer Sebagai Seni Berkomunikasi Secara Tulis, Ultimacomm: Jurnal Ilmu Komunikasi 2(1), 2010, pp. 64-70.

[11] N. A. Yensy, Efektifitas pembelajaran statistika matematika melalui media whatsapp group ditinjau dari hasil belajar mahasiswa (masa pandemik Covid 19). Jurnal Pendidikan Matematika Raflesia 5(2), 2020, pp. 65-74.

[12] S. Sakaria, A. Nojeng, Bahan Ajar Menulis Opini dan Esai dengan Pembelajaran Berbasis Proyek, RETORIKA: Jurnal Bahasa, Sastra, dan Pengajarannya 11(1), 2018, pp. 68-76.

[13] P. Pahriah, B. R. A. Safitri, Pelatihan dan Pendampingan Penulisan Buku Ajar Bagi Dosen Pemula Melalui Whatsapp Group, Lumbung Inovasi: Jurnal Pengabdian kepada Masyarakat 5(1), 2020, pp. 9-15.

[14] D. P. Parlindungan, G. P. Mahardika, D. Yulinar, Efektivitas Media Pembelajaran Berbasis Video Pembelajaran dalam Pembelajaran Jarak Jauh (PJJ) di SD Islam An-Nuriyah, Prosiding Seminar Nasional Penelitian LPPM UMJ. Vol. 1(1), 2020.

[15] R. Suryani, Fungsi Whatsapp Grup Shalihah Cabang Bandar Lampung Sebagai Pengembangan Media Dakwah Dalam Membentuk Akhlakul Karimah, Doctoral dissertation. UIN Raden Intan Lampung, 2017.

[16] S. Susilawati, T. Supriyatno, Online learning through WhatsApp group in improving learning 
motivation in the era and post pandemic COVID19, Jurnal Pendidikan: Teori, Penelitian, dan Pengembangan 5(6), 2020, pp. 852-859.

[17] H. Santoso, Agus, Cerdas Memenangkan Lomba Karya Ilmiah, 2010, 1st ed. Yogyakarta: Interpree Book.

[18] S. Sudarmini, S. Yumartati, Pelatihan penulisan artikel populer bagi guru SMP Unggulan Aisyiyah Bantul, Seminar Nasional Hasil Pengabdian Kepada Masyarakat, 2019, pp. 657-662.

[19] Trisnani, Pemanfaatan Whatsapp Sebagai Media Komunikasi Dan Kepuasan Dalam Penyampaian Pesan Dikalangan Tokoh Masyarakat, Jurnal Komunika: Jurnal Komunikasi, Media dan Informatika 6(3), 2017, pp. 1-12.

[20] W. Darmalaksana, R. Hambali, A. Masrur, Muhlas, Analisis pembelajaran online masa wfh pandemic covid-19 sebagai tantangan pemimpin digital abad 21, Karya Tulis Ilmiah (KTI) Masa Work From Home (WFH) Covid-19 UIN Sunan Gunung Djati Bandung, 2020, pp. 1-12.

[21] Y. Ardianto, Memahami Metode Penelitian Kualitatif, DJKN Kementerian Keuangan, 2020.

[22] A. Zuhri, Menjadi Penulis Independen, 2008. 